\title{
SYNTHESIS, CHARACTERIZATION AND SUPEROXIDE DISMUTASE ACTIVITY OF THE MANGANESE(II) MIXED LIGAND COMPLEXES CONTAINING SULFATHIAZOLE
}

\author{
J.R. ANACONA* AND JESUS DIAZ \\ Departamento de Química. Universidad de Oriente. Apartado Postal 208. Cumana. Venezuela.
}

(Received: January 3, 2008 - Accepted: October 20, 2008)

\begin{abstract}
Manganese(II) metal ion and sulfathiazole (Hstz) react with pyrrolidine (pyrro), piperidine (pipe) and ethylenediamine (en) to form the following mixed ligand complexes : $\left[\mathrm{Mn}(\mathrm{stz})_{2}(\text { pyrro })_{2}\right],\left[\mathrm{Mn}(\mathrm{stz})_{2}(\text { pipe })_{2}\right]$ and $\left[\mathrm{Mn}(\mathrm{stz})_{2}(\mathrm{en})_{2}\right]$ which were characterized by physicochemical and spectroscopic methods. Their spectra indicated that the sulfathiazole is probably acting as a monoanionic unidentate chelating agent. The superoxide dismutase mimetic activity of the complexes was investigated using the indirect xanthine-xanthine oxidase-nitroblue tetrazolium method and compared to that of the native enzyme.
\end{abstract}

\section{INTRODUCTION}

Superoxide dismutase (SOD) is an enzyme that has attracted the interest of researchers with different approaches and goals. It catalyses the dismutation of the superoxide radical very efficiently through a redox reaction of its copper centre ${ }^{1,2}$. The mechanism believed to be operating in the metalloproteins involves one-electron reduction of a metal ion by superoxide followed by re-oxidation of the reduced metal ion by a second superoxide anion ${ }^{3,4}$. Metal complexes that can undergo such redox cycling are likely to function as superoxide scavengers as copper has been proven to be the active metal center in the best studied SOD, many copper complexes have been synthesized and tested for SODlike activity ${ }^{5-17}$, and most of them appeared to be very efficient. The other two classes of SODs that contain iron or manganese have received less attention and their structures have only been recently described ${ }^{18-20}$. However, some iron $^{8,21,22}$, manganese ${ }^{8,21,23}$, ruthenium ${ }^{24}$ and cobalt ${ }^{25}$ SOD mimics have been reported and some of them show a marked SOD activity and seem to retain it in living cells $\mathrm{s}^{26,27}$.

The complex formation between metal ions and sulfa drugs has been extensively studied with a view to establish the relationship and importance of metal-drug interactions $\mathrm{s}^{28-32}$. The results seem to suggest that the different behaviour of the ligand depends on its deprotonation and/or the metal ion, and it is difficult to give a generally valid account of the metal-sulfonamide structures As a consequence, three types of behaviour of the sulfathiazole have been observed; in neutral form and deprotonated, when it can act as a monodentate or bidentate ligand. However, we reported the synthesis and structure of $[\mathrm{Cu}($ en) $\left.{ }_{2}\left(\mathrm{OH}_{2}\right)_{2}\right][\text { sulfathiazole }]_{2}$ where the sulfathiazole behaves as a deprotonated counter ion ${ }^{33}$. Following with our studies on metal drugs interactions, we report here the preparation, characterization and superoxide dismutase activity of the manganese(II) mixed ligand complexes containing sulfathiazole. The structural formulae for Hstz, pyrro, pipe and en are shown in Figure 1.

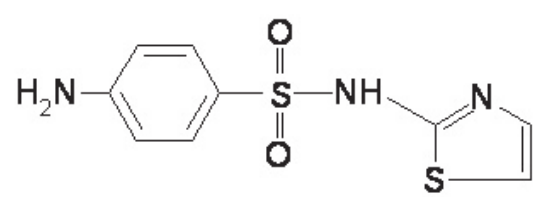

(Hstz)<smiles>C1CCNC1</smiles>

(pyrro)<smiles>C1CCNCC1</smiles>

(pipe)<smiles>NCCN</smiles>

\section{EXPERIMENTAL}

\section{Materials}

$\mathrm{MnCl}_{2} \cdot 4 \mathrm{H}_{2} \mathrm{O}$, sulfathiazole, pyrrolidine, piperidine and ethylenediamine were purchased from Aldrich. Xanthine, xanthine oxidase, nitroblue tetrazolium chloride monohydrate (NBT) and superoxide dismutase (bovine erythrocytes) were obtained from Sigma Chemical Co.

\section{Synthesis}

$\mathrm{MnCl}_{2} .4 \mathrm{H}_{2} \mathrm{O}(1 \mathrm{mmol})$ was added to a solution of sulfathiazole $(2 \mathrm{mmol})$ in $\mathrm{MeOH}^{2}(50 \mathrm{~mL})$. Then to the resulting mixture, $(1.0 \mathrm{~mL}, 10 \mathrm{mmol})$ of pyrrolidine was added. Following the addition, the mixture was refluxed for two days and the boiling solution was then filtered and concentrated. A maroon precipitated formed. It was filtered and purified by recrystallization from dimethylformamide. The mixed ligand complexes containing pipe or en were prepared under the same conditions.

\section{Physical techniques}

Infrared spectra of the ligand and its metal complexes were recorded on a FT-IR Spectrophotometer Spectrum 2000, Perkin Elmer; samples were prepared in $\mathrm{KBr}$ pellets. UV-Vis spectra were recorded using a Perkin-Elmer spectrometer. C, H, N and S were analyzed on a LECO CHNS 932 model microanalytical instrument. Metal content was estimated spectrophotometrically on an atomic absorption spectrometer. Magnetic susceptibility was measured on a Johnson Matthey Susceptibility Balance at room temperature using $\mathrm{HgCo}(\mathrm{NCS})_{4}$ as calibrant. Corrections for the diamagnetism of the complex were estimated from Pascal constants. EPR spectra were recorded on a Brucker ECS 106 spectrometer by the X-band method. Thermogravimetric analyses were performed with a Cahn $\mathrm{RG}$ electromicrobalance in air at a heating rate of $4{ }^{\circ} \mathrm{C} \min ^{-1}$ up to $400{ }^{\circ} \mathrm{C}$.

\section{Superoxide assays}

Superoxide dismutase activity of the complex was determined by using its ability to inhibit the reduction of NBT by superoxide ions generated by the xanthine / xanthine oxidase system ${ }^{34}$. The extent of NBT reduction was followed spectrophotometrically by measuring the absorbance at $560 \mathrm{~nm}$. The aqueous reaction mixture contained $2 \times 10^{-4} \mathrm{M}$ xanthine, $5 \times 10^{-5} \mathrm{M} \mathrm{NBT}$ and $1.25 \times 10^{-2} \mathrm{M}$ sodium phosphate buffer at $\mathrm{pH} 7.5$ and $25^{\circ} \mathrm{C}$. For comparative purposes, we have also measured the activity of native superoxide dismutase, from bovine erythrocytes, under the same experimental conditions. Five assays were performed for each concentration of both SOD and the metal complex. We checked that the generating xanthine/xanthine oxidase system was not inhibited by our metal complex by following, at $295 \mathrm{~nm}$, the uric acid produced when xanthine is oxidized by xanthine oxidase in aerobic conditions concomitantly to the production of superoxide ions.

\section{RESULTS AND DISCUSSION}

The elemental analyses agree well with a 1:1:1 metal to ligand stoichiometry for all the complexes (Table 1). They are coloured and appears to be air stable solids. They are insoluble in water and other common organic solvents such as ethanol, benzene, acetone, acetonitrile, ether and pyridine but soluble in DMSO. Thermograms

Fig. 1 Structural formulae of the ligands 
Table 1. Elemental analyses for the manganese(II) mixed ligand complexes

\begin{tabular}{|l|l|l|c|c|c|}
\hline & \multicolumn{2}{|l|}{ Found (Calcd.) $\%$} & & \\
Compound & \multicolumn{2}{|l|}{$\mathrm{N}$} & \multicolumn{1}{|c|}{$\mathrm{H}$} & $\mathrm{S}$ & Metal \\
\hline$\left[\mathrm{Mn}\left(\mathrm{C}_{26} \mathrm{H}_{36} \mathrm{~N}_{8} \mathrm{O}_{4} \mathrm{~S}_{4}\right)\right]$ & 43.5 & 15.9 & 4.6 & 18.1 & 7.8 \\
{$\left[\mathrm{Mn}(\mathrm{stz})_{2}(\text { pyrro })_{2}\right]$} & $(43.0)$ & $(15.5)$ & $(5.0)$ & $(17.7)$ & $(7.6)$ \\
\hline$\left[\mathrm{Mn}\left(\mathrm{C}_{28} \mathrm{H}_{40} \mathrm{~N}_{8} \mathrm{O}_{4} \mathrm{~S}_{4}\right)\right.$ & 44.2 & 15.3 & 5.2 & 17.5 & 7.3 \\
{$\left[\mathrm{Mn}(\mathrm{stz})_{2}(\mathrm{pipe})_{2}\right]$} & $(44.6)$ & $(14.9)$ & $(5.6)$ & $(17.0)$ & $(7.3)$ \\
\hline$\left[\mathrm{Mn}\left(\mathrm{C}_{22} \mathrm{H}_{34} \mathrm{~N}_{10} \mathrm{O}_{4} \mathrm{~S}_{4}\right)\right]$ & 37.8 & 20.4 & 5.3 & 17.9 & 7.9 \\
{$\left[\mathrm{Mn}(\mathrm{stz})_{2}(\mathrm{en})_{2}\right]$} & $(37.6)$ & $(19.9)$ & $(5.1)$ & $(18.2)$ & $(7.8)$ \\
\hline
\end{tabular}

of the metal mixed complexes indicate endothermic decompositions with no water and solvent molecules. The experimental conductivity values in DMSO solutions falls in the range of a 1:1 electrolyte. Attempts to form mixed ligand complexes of a well defined stoichiometry, under the above mentioned conditions, with pyridine, 5-nitro barbituric acid, 2-picoline, diethylenetriamine, quinoline, 2,6-dichloropyridine, nicotinic acid, 2,6-lutidine, 2,2-bipyridine, neocuproine and 1,10-phenanthroline were unsuccessful.

\section{IR spectra}

The IR spectra of sulfathiazole and its complexes have been assigned mainly for those specific frequencies directly involved in complex formation. The presence of $v(\mathrm{Mn}-\mathrm{N})$ stretching vibrations in the $420-460 \mathrm{~cm}^{-1}$ range for the metal complexes (absent in the free ligands) provide evidence that the sulfathiazole with pyrrolidine, piperidine or ethylenediamine moieties are bonded to the metal ion through the nitrogen atoms. The usual modes of the sulfathiazole ligand are also present. The bands of 3320 and $3280 \mathrm{~cm}^{-1}$, assigned to the $v_{\text {as }}(\mathrm{N}-\mathrm{H})$ and $v_{\mathrm{s}}(\mathrm{N}-\mathrm{H})$ vibrations respectively of the $\mathrm{NH}_{2}$ group, are not shifted in the complex, suggesting coordination through $\mathrm{N}$-thiazole ring. As expected, the bands due to $v\left(\mathrm{SO}_{2}\right)_{2}\left(1320 \mathrm{~cm}^{-1}\right), v\left(\mathrm{SO}_{2}\right)_{\mathrm{s}}\left(1140 \mathrm{~cm}^{-1}\right)$, scissoring and wagging $\mathrm{SO}_{2}\left(570\right.$ and $\left.550 \mathrm{~cm}^{-1}\right)$ vibration modes respectively remain unchanged. There is no change of the bands at 1540, 920 and $680-640$ $\mathrm{cm}^{-1}$, which have been assigned to the characteristic thiazole ring and $v(\mathrm{~S}-\mathrm{N})$ and $v(\mathrm{C}-\mathrm{S})$ vibrations, respectively, suggesting also coordination through the $\mathrm{N}$-thiazole ring.

\section{Electronic spectra}

The UV-Vis spectra of sulfathiazole and their complexes in DMSO solutions present absorption maxima attributable to the ligands. The band in the $250-270 \mathrm{~nm}$ is assigned to a $\pi \rightarrow \pi^{*}$ transitions within the organic molecule. An intraligand band at $290-300 \mathrm{~nm}$ is related to the $\pi \rightarrow \pi^{*}$ transitions within the thiazole moiety ${ }^{27,28}$. The band in the $360-380 \mathrm{~nm}$ region is ascribed to an intraligand transition of the $\mathrm{n} \rightarrow \pi^{*}$ type in accordance with the literature data for transitions due to sulphur atoms $\mathrm{s}^{27,29}$. The fact that the bands due to sulphur atoms are not shifted suggests that this atom is not involved in coordination to metal ions.

Because of the unsaturation of the sulfathiazole, the intense UV absorption has a tail in the visible region and this hampers assignment of the relatively weak and spin forbidden d-d transitions of the manganese(II) ion, which with S $=5 / 2$ has no excited states of the same spin multiplicity as the ground state. The $\left[\mathrm{Mn}(\mathrm{stz})_{2}(\text { pyrro })_{2}\right],\left[\mathrm{Mn}(\mathrm{stz})_{2}(\text { pipe })_{2}\right]$ and $\left[\mathrm{Mn}(\mathrm{stz})_{2}(\mathrm{en})_{2}\right]$ complexes showed a broad absorption band of mensurable intensity at 520-540 nm range.

\section{Magnetic measurements}

The corrected magnetic moments were calculated from the molar magnetic susceptibilities using Pascal constants. The manganese(II) complexes have magnetic moments in the $5.86-6.10$ B.M. range as predicted for high spin $\mathrm{d}^{5}$ systems with five unpaired electrons. All complexes gave EPR signal at room and liquid nitrogen temperatures. No hyperfine splitting could be observed due to ${ }^{55} \mathrm{Mn}(100 \%$ natural abundance, $\mathrm{I}=5 / 2)$. The mixed complexes showed the same broad signal centred at $3500 \mathrm{G}$ with $\mathrm{g}$ values 2.17-2.19 and a linewidth of $700 \mathrm{G}$.

\section{Structure of the complexes}

Despite the crystalline nature of the products, neither proved suitable for Xray structure determination. However, an inspection of molecular models, along with consideration of the structure found previously by X-ray crystallography, for a similar complex [pyrrolidinium] $\left[\mathrm{Co}(\mathrm{stz})_{3}(\text { pyrro) }]^{35}\right.$ containing a $\mathrm{N}_{4}$ donor set, suggested that $\left[\mathrm{Mn}(\mathrm{stz})_{2}(\text { pyrro })_{2}\right]$ and $\left[\mathrm{Mn}(\mathrm{stz})_{2}(\text { pipe })_{2}\right]$ may have tetrahedral geometry around central atom. The sulfathiazole ligand has several potential donor atoms, but due to steric constraints, it is probably acting as a monoanionic unidentate chelating agent.

\section{Superoxide dismutase activity}

Superoxide anions have a very short half life and, accordingly, they must be produced continuously. In this colorimetric based assay, superoxide ions are generated from the conversion of xanthine and oxygen to uric acid and hydrogen peroxide by xanthine oxidase. The superoxide anion then converts NBT to formazan, a colored product that absorbs light at $560 \mathrm{~nm}$. SOD reduces the superoxide ion concentration and thereby lowers the rate of formazan formation. In the SOD-like activity test, the metal complexes compete with NBT for oxidation of the generated superoxide ions. The more efficient the complex, the lower the concentration that corresponds to $50 \%$ inhibition of NBT reduction; this concentration is termed $\mathrm{IC}_{50}$ for comparative purposes. Figure 2 shows the percentage of inhibiting NBT reduction with an increase in the concentration of the mixed ligand manganese(II) complexes.

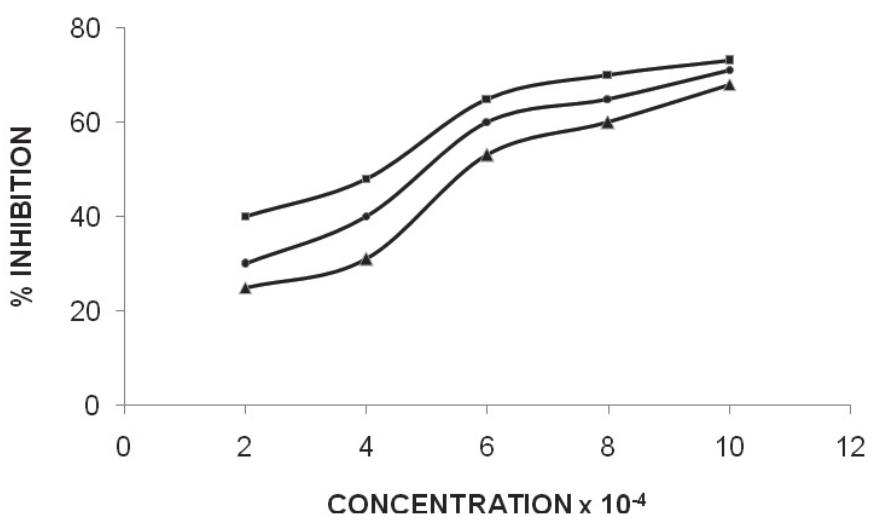

Figure 2. Percentage of inhibiting NBT reduction with an increase in the concentration of mixed ligand manganese(II) complexes.

- $\left[\mathrm{Mn}(\mathrm{stz})_{2}(\mathrm{en})_{2}\right], \bullet \bullet\left[\mathrm{Mn}(\mathrm{stz})_{2}(\text { pipe })_{2}\right], \boldsymbol{\Delta}\left[\mathrm{Mn}(\mathrm{stz})_{2}(\text { pyrro })_{2}\right]$.

On a molar basis the catalytic activity of the manganese(II) mixed complexes were : $\left.\left[\mathrm{Mn}(\text { stz) })_{2}(\text { pyrro })_{2}\right] \mathrm{IC}_{50}=580 \mu \mathrm{M},\left[\mathrm{Mn}(\text { stz) })_{2} \text { pipe }\right)_{2}\right] \mathrm{IC}_{50}$ $=500 \mu \mathrm{M},\left[\mathrm{Mn}(\mathrm{stz})_{2}(\mathrm{en})_{2}\right] \mathrm{IC}_{50}=420 \mu \mathrm{M}$ and SOD $\mathrm{IC}_{50}=0.042 \mu \mathrm{M}$. The catalytic activity of the $\left[\mathrm{Mn}(\mathrm{stz})_{2}(\mathrm{en})_{2}\right]$ complex corresponds to $0.01 \%$ of that of native SOD. An activity of ca. $0.1 \%$ of that of the enzyme may be considered as quite interesting, considering the strong activity, but also the high molecular weight of SOD itself. Higher percentages of SOD activity have been

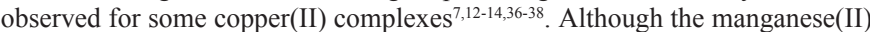
complexes have interesting $\mathrm{IC}_{50}$ values, they present a serious disadvantage. It does not go beyond $75 \%$ inhibition, whereas copper complexes tested; $\left[\mathrm{Cu}(\mathrm{stz})\right.$ (pyridine) $\left.{ }_{3} \mathrm{Cl}\right], \quad\left[\mathrm{Cu}(\mathrm{Hstz})_{2}(\mathrm{MeOH}) \mathrm{Cl}_{2}\right]$ and $\left[\mathrm{Cu}(\mathrm{Hstz})_{2}(\mathrm{EtOH}) \mathrm{Cl}_{2}\right]$ reach $85 \%$ inhibition or more ${ }^{30-32}$. This kind of flattening of the curves below $100 \%$ inhibition have already been observed for other metal complexes, but the kinetic reasons for such a limitation have not been explained ${ }^{9,10}$.

\section{CONCLUSION}

The manganese(II) mixed complexes tested in this work have been shown to compete successfully with NBT toward the superoxide ion. Although the SOD activity is not higher than some already reported, they present higher percentages of SOD activity than the $\left.[\mathrm{Co} \text { (quinoline) })_{2}(\mathrm{SH})_{2}\right]$ complex [26] (which it does not go beyond $60 \%$ inhibition) and appear to be promising SOD mimics.

\section{ACKNOWLEDGEMENTS}

Our sincere thank to the Comision de Investigacion of the Universidad de Oriente for providing financial support. 


\section{REFERENCES}

1. F. Saczewski, E. Dziemidowicz-Borys, P.J. Bednavski and M. Gdaniec, Arch. Pharm. (Weinheim), 340, 333, (2007)

2. F. Saczewski, E. Dziemidowicz-Borys, P.J. Bednavski, R. Grunert, M. Gdaniec and P. Tabin, J. Inorg. Biochem. 100, 1389, (2006)

3. A. Casado, R. De la Torre and M. Lopez-Fernandez, Indian J. Med. Res. 125, 655, (2007)

4. F.S. Raza, M. Okamoto, H. Takemori and G.P. Vinson, J. Endocrinol. 184 77, (2005)

5. A. Gartner and U. Weser, in F. Vogtle and E. Weber, (Eds.), Topics in Current Chemistry, Springer, Berlin, 1986, Vol. 132

6. R. Brigelius, R. Spottl, W. Bors, E. Lengfelder, M. Saran and U. Weser, FEBS Lett., 47, 72, (1974)

7. S. Goldstein and G. Czapski, J. Am. Chem. Soc., 105, 7276, (1983)

8. A. Bury, A.E. Underhill, D.R. Kemp, N.J. O’Shea, J.P. Smith and P.S. Gomm, Inorg. Chim. Acta, 138, 85, (1987)

9. C.J. Bijloo, H. Van der Goot, A. Bast and H. Timmerman, J. Inorg. Biochem., 40, 237, (1990)

10. R.G. Bhirud and R.S. Srivastava, J. Inorg. Biochem., 40, 331, (1990)

11. S. Goldstein, G. Czapski and D. Meyerstein, J. Am. Chem. Soc., 112, 6489 , (1990)

12. R.G. Bhirud and T.S. Srivastava, Inorg. Chim. Acta, 179, 125, (1991)

13. A.E. Underhill, S.A. Bougourd, M.L. Flugge, S.E. Gale and P.S. Gomm, J. Inorg. Biochem., 52, 139, (1993)

14. L.L. Costanzo, G. Deguidi, S. Giuffrida, E. Rizzarelli and G. Vecchio, $J$ Inorg. Biochem., 50, 273, (1993)

15. Q. Luo, Q. Lu, A. Dai and L. Huang, J. Inorg. Biochem., 51, 655, (1993)

16. J.R. Anacona, C. Rodriguez and C. Rodriguez-Barbarin, Monats. fur Chemie, 135, 785, (2004)

17. J.R. Anacona, O. Nusetti, C. Gutierrez and D. Loroño, J. Coord. Chem. $\mathbf{5 5}$, 1433, (2002).

18. L. Stoddard, F.L. Howell, D. Ringe and G.A. Fetsko, Biochemistry., 29, 8885, (1990)

19. K. Weighart, Angew. Chem. Int. Ed. Engl., 28, 1153, (1989)
20. M.W. Parker and C.C.F. Blake, J. Mol. Biol., 199, 649, (1988)

21. Y. Nishida, I. Watanabe and K. Unoura, Chem. Lett., 1517, (1991)

22. T. Nagano, T. Hirano and M. Hirobe, J. Biol. Chem., 264, 9243, (1989)

23. F.S. Archibald and I. Fridovich, Arch. Biochem. Biophys., 214, 452, (1982)

24. E. Bienvenue, S. Choua, M.A. Lobo-Recio, C. Marzin, P. Pacheco,P. Seta and T. Tarrago, J. Inorg. Biochem., 57, 157, (1995)

25. H.D. Rabinowitch, C.T. Privalle and I. Frodivich, Free Rad. Biol. Med., 3, $125,(1987)$

26. J.R. Anacona, M. Azocar, O. Nusetti and C. Rodriguez-Barbarin, Transition Met. Chem. 28, 24, (2003)

27. J. Lumsden and D.O. Hall, Biochem. Biophys. Res. Commun., 64, 595, (1975)

28. A. Bult, Metal complexes of sulfanilamides. In: Sigel (Ed.), Metal Ions in Biological Systems, Vol. 16, New York. 1983

29. J. Casanova, G. Alzuet, S. Ferrer, J. Borras, S. Garcia-Granda and E. Perez-Carreño, J. Inorg. Biochem., 51, 689, (1993)

30. J. Casanova, G. Alzuet, J. Borras, J. Latorre, M. Sanau and S. GarciaGranda, J. Inorg. Biochem., 60, 219, (1995)

31. J. Casanova, G. Alzuet, J. Borras, J. Timoneda, S. Garcia-Granda and I.Candano-Gonzalez, J. Inorg. Biochem., 56, 65, (1994)

32. J. Casanova, G. Alzuet, J. Borras and O. Carugo, J. Chem. Soc., Dalton Trans., 2239, (1996)

33. J.R. Anacona, N. Ramos, G. Diaz-Delgado and E.M. Roque, J. Coord. Chem., 55, 901, (2002)

34. L.W. Oberley and D.R. Spitz, in R.A. Greenwald (Ed). Handbook for Methods for Oxygen Radicals Research, CRC Press. Boca Ratón, FL, vol 217, 1986

35. J.R. Anacona, D. Loroño, M. Azocar and R. Atencio, J. Coord. Chem (2008). In press DOI 10.1080/00958970802376265.

36. M. Linss and U. Weser, Inorg. Chim. Acta, 138, 163, (1987)

37. J.S. Richardson, D.C. Richardson, J.A. Trainer and E.D. Geltzoff, Nature (London), 306, 284, (1983)

38. C. Amar, E. Wilkas and J. Foos, J. Inorg. Biochem. 17, 313, (1982) 